\title{
CELL PROLIFIRATION ACTIVITY IN LYMPH NODES INFECTED BY PORCINE CIRCOVIRUS-2
}

\author{
Inga Pigiṇka-Vjačeslavova ${ }^{1}$, Edīte Birğele ${ }^{2}$ \\ ${ }^{1}$ Institute of Food Safety, Animal Health and Environment BIOR, Latvia \\ ${ }^{2}$ Latvian University of Agriculture \\ piginka@inbox.lv
}

\begin{abstract}
High economic losses in agriculture can be caused by pig disease like Postweaning Multisystemic Wasting Syndrome (PMWS). Porcine circovirus-2 (PCV2) is the primary agent of PMWS. It is known that PMWS causes cellular and humoral immunity disorders, therefore it is considered a general immune deficiency disease in piglets. It is still unknown, why piglets with PMWS have severe loss of lymphocytes in lymphoid tissues and in the blood. Thus, the hypothesis of the study was that lymphocyte depletion occurs because of lymphocyte life-cycle delay in pigs infected by PCV2. The activity of cell life-cycle is attributed to protein Ki67. This protein is found in all active phases of the cell like interphase G1, S, G2 and mitoses. However, protein Ki67 is not observed at all in the cell's "quiet" phase G0. The aim of our work was to investigate the lymph node cell proliferation activity of pigs infected by PCV2. In total, 42 pig carcasses were collected from 5 to 15 weeks old pigs with PMWS clinical manifestation. Lymph nodes were selected from each pig carcass for histological and imunohistochemical testing. We concluded that B lymphocyte population was reduced first in the lymph node with PCV2, but the number of T lymphocytes decreased later. PCV2 decreased B lymphocyte prolifiration activity.
\end{abstract}

Key words: Ki67, CD79 $\alpha$, CD3, lymphocyte, pig.

\section{Introduction}

Pig breeding is one of the main agricultural sectors in Latvia. According to the data of the Latvian Statistic Center, 305,521 pigs were registered in 2016. The swine production comprises $8 \%$ of the total agricultural production in Latvia. High economic losses in agriculture can be caused by pig disease like Postweaning Multisystemic Wasting Syndrome (PMWS). This disease develops in $10-30 \%$ cases of naturally infected pigs (Darwich, Segales, \& Mateu, 2004). Mortality of PMWS is within very variable range of $4-30 \%$ and $70-80 \%$, depending on the underlying health status of animals from the affected farm (Segales \& Domingo, 2002).

Porcine circovirus-2 (PCV2) is etiological agent of PMWS. PCV2 infection is distributed worldwide throughout the domestic pig population. The first report about PCV2 infection in Lithuania and Latvia was published in 2007 (Stankevicius et al., 2007).

Clinical confirmation of PMWS is difficult, because this disease has non-specific clinical features and non-specific gross pathology. Manifestations of the disease are weight loss, diarrhea or respiratory disorder, pale or icteric mucouses (Rosell et al., 1999; Segales et al., 2004). Specific changes of PCV2 appear only in the microscopic structure of the lymph nodes (Rosell et al., 1999). This virus replicates in macrophages, therefore, lymph node lymphocytes are "substituted" by the macrophages (Sanchez et al., 2003). It is known that PMWS causes cellular and humoral immunity disorders, therefore, it is considered as a general immune deficiency disease in piglets (Segales et al., 2004; Ferrari et al., 2014).

It is still unknown why piglets with PMWS have severe loss of lymphocytes in lymphoid tissues and in the blood. Some human and animal viruses can cause lymphoid tissue apoptosis (Benedict, Banks, \& Ware, 2003; Irusta, Chen, \& Hardwick, 2003). Apoptosis is a programmed cell death and is developed by activation of specific enzyme caspases (Hengartner, 2000; Lockshin \& Zakeri, 2004). However, the latest results reveal that apoptosis has no significant impact on lymphocyte depletion in lymph nodes of pigs infected by PCV2 (Kiupel et al., 2005; Resendes et al., 2004; Resendes et al., 2011).

Thus, the hypothesis of the study was: lymphocyte depletion occurs because of lymphocyte life-cycle delay in pigs infected by PCV2. The activity of cell life-cycle is attributed to protein Ki67, which is found in all active phases of the cell, like interphase G1, S, G2 and mitoses. However, protein Ki67 is not observed at all in the cell's "quiet" phase G0. The aim of our work was to investigate the lymph node cell proliferation activity of pigs infected by PCV2.

\section{Materials and Methods}

Five pig farms were investigated in Latvia from 2008 to 2011. The clinical manifestation of PMWS and mortality of piglets was reported in all investigated farms at different mortality ranges. Such PMWS clinical manifestations as weight loss, diarrhea or respiratory disorder, pale or icteric mucouses were observed before the death of piglets. In total, 42 pig carcasses were collected; the age of investigated pigs being that of 5-15 weeks. Two lnn. inguinales superficiales, three lnn. jejunales and three $\ln n$. tracheobronchales were selected from each animal for histological and imunohistochemical testing.

Lymph node samples were fixed by neutralbuffered $10 \%$ formalin for $24 \mathrm{~h}$ at room temperature 
and were processed using a Leica TP1020 automated tissue processor with standart protocol, after that embeded into parafine. Four micron thick sections were cut and floated onto Plus slides. Standart deparaffinization protocol was run for all slides. One slide from each lymph node was stained by hematoxylin and eosin. Four slides from each lymph node were stained by imunohistochemistry for PCV2, CD3, CD79 $\alpha$ and Ki67 detection.

PCV2 detection protocol included tissue blocking with $3 \%$ hydrogen peroxide for $30 \mathrm{~min}$, after that proteinase $\mathrm{K}$ was used for epitope demasking; primary antibody (Ingenasa 36A9) was diluted 1:250 with TBS and albumin; primary antibody was incubated for 45 min at $+4{ }^{\circ} \mathrm{C}$, for 15 hours. Secondary antibody Policlonal Goat-Anti Mouse Immunoglobulin Biotinylated was diluted 1:200 with TBS and applied at room temperature for one hour. Then avidin peroxidase conjugated kit was applied to the tissue slide and incubated for two hours at room temperature. After that the chromogen-substrate (AEC) was added, stained by hematoxylin and covered by mounting media with coverslip.

Microwave was used for CD3, CD79 $\alpha$ imunohistochemical staining and Ki67 detection for epitope demasking (incubation for 15 minutes by 350 watts and 7 minutes by 750 watts); after that endogene peroxidase of tissues was blocked with $3 \%$ hydrogen peroxide for $10 \mathrm{~min}$. Each slide from one lymph node was applied to by three different primary antibodies. One slide was applied to by primary antibody Monoclonal Mouse Anti-Rat Ki67Antigen, Clone MIB-5 for Ki67 protein detection, which is a specific protein of cell life activity (Polaček et al., 2007; Debeer et al., 2013); to the second slide a primary antibody Monoclonal Mouse Anti-Human CD3, Clone F7.2.38 was added for CD3 positive cell visualization, which is a T lymphocyte (Polaček et al., 2007; García-Nicolás et al., 2015); the third slide was applied to by primary antibody Monoclonal Mouse Anti-Human CD79 $\alpha$, Clone JCB117 for CD79 $\alpha$ protein, which is B lymphocyte specific protein (Polaček et al., 2007; Debeer et al., 2013; García-Nicolás et al., 2015). After that all slides were incubated in DakoEnVision polymer-HRP (Policlonal Goat-Anti Mouse Immunoglobulins) at room temperature for 45 minutes. At the end, they were washed by TBS, added chromogen-substrate (DAB), stained by hematoxylin and covered by mounting media with coverslip.

The tissue evaluation was done according to the common system, quantity of PCV2 antigen was expressed by plus system:

- mild quantity of PCV2 antigen $(+)$ was observed in less than $10 \%$ of the follicles (Opriessnig, Meng, \& Halbur, 2007) or lymph node parenchyma;
- moderate quantity of PCV2 antigen (++) was observed in $10 \%$ to $50 \%$ of the follicles (Opriessnig, Meng, \& Halbur, 2007) or lymph node parenchyma;

- severe quantity of PCV2 antigen (+++) was observed in more than $50 \%$ of the follicles (Opriessnig, Meng, \& Halbur, 2007) or lymph node parenchyma.

CD3, CD79 $\alpha$ and Ki67 positive cells were evaluated in different layers of the lymph node: in the follicles, in paracortex near the follicles, in paracortex near sinuses and in medulla of lymph node. In each layer of lymph node, five randomly selected fields were analyzed. In each field, 100 cells with magnification x400 were counted. A microscope Zeiss Axiolab with cell counting program Zeiss version 4.10 was used.

The average quantity and standard deviation was used for CD3, CD79 $\alpha$ and Ki67 positive cells. T-test was used to detect significant differences for CD3, CD79 $\alpha$ and Ki67 positive cell quantity in different layers of the lymph node with and without PCV2.

To determine the correlation between number of CD3, CD79 $\alpha$ and Ki67 positive cells in different layers of the lymph node and quantity of PCV2 antigen, Spearman's rank correlation coefficient of SPSS Statistics version 22 (IBM Corporation, Chicago, Illinois) was used.

\section{Results and Discussion}

The study results are summarized in Table 1, where CD3, CD79 $\alpha$ and Ki67 positive cell quantity in different layers of the lymph node is with and without PCV2. The correlation between the increasing quantity of PCV2 in lymph node and number of CD79 $\alpha$, CD3 and Ki67 positive cells in the various layers of the lymph node is examined additionally (Table 2).

These results reveal that CD79 $\alpha$ positive cells are significantly different in all layers of the lymph node with and without PCV2 antigen (Table 1). Negative correlation of CD79 $\alpha$ positive cells was observed with increasing quantity of PCV2 in lymph node, but it is statistically significant only in cortex $\left(\mathrm{r}_{\mathrm{s}}=-0.587\right)$ and paracortex near follicle $\left(r_{s}=-0.339\right)$ (Table 2). It means that $\mathrm{CD} 79 \alpha$ positive cells are significantly reduced in cortex and paracortex near follicle with increasing quantity of PCV2 in the lymph nodes.

The number of CD3 positive cells in all layers of the lymph node with moderate and severe PCV2 quantity was significantly lower than in the lymph node without PCV2 antigen (Table 1). Besides that, the number of $\mathrm{CD} 3$ positive cells in all layers of the lymph node with mild quantity of PCV2 and moderate changes of follicle visualization or unvisible follicles in lymph node was significantly lower than in the lymph node without PCV2 antigen. In lymph nodes without and with PCV2 where were mild changes in 
Table 1

\section{Average number of CD79, CD3 and Ki67 positive cells in lymph nodes with and without PCV2}

\begin{tabular}{|c|c|c|c|c|}
\hline PCV2 in lymph node & Layers of lymph node & $\begin{array}{l}\text { CD79 } \alpha \text { positive } \\
\text { cells } \pm \text { standard } \\
\text { deviation }\end{array}$ & $\begin{array}{c}\text { CD3 positive } \\
\text { cells } \pm \text { standard } \\
\text { deviation }\end{array}$ & $\begin{array}{c}\text { Ki67 positive } \\
\text { cells } \pm \text { standard } \\
\text { deviation }\end{array}$ \\
\hline \multirow[t]{4}{*}{ PCV2 negative } & cortex & $48.7 \pm 8.0^{\mathrm{a}}$ & $0.0 \pm 0.0^{\mathrm{e}}$ & $92.8 \pm 1.9^{k}$ \\
\hline & paracortex near follicule & $18.6 \pm 5.4^{b}$ & $97.1 \pm 1.3^{\mathrm{f}}$ & $15.2 \pm 4.0^{1}$ \\
\hline & paracortex near sinus & $42.9 \pm 10.4^{b}$ & $96.7 \pm 1.1^{\mathrm{g}}$ & $0.0 \pm 0.0^{\mathrm{n}}$ \\
\hline & medulla & $21.9 \pm 10.0^{\mathrm{d}}$ & $64.8 \pm 3.1^{\mathrm{h}}$ & $19.0 \pm 8.9^{\mathrm{m}}$ \\
\hline \multirow{4}{*}{$\begin{array}{l}\text { PCV2 }(+) \text { and mild changes } \\
\text { of follicle visualization in } \\
\text { lymph node }\end{array}$} & cortex & $32.8 \pm 4.3$ & $0.0 \pm 0.0$ & $76.3 \pm 6.8$ \\
\hline & paracortex near follicule & $7.9 \pm 3.7$ & $100.0 \pm 0.0$ & $44.6 \pm 3.0^{1}$ \\
\hline & paracortex near sinus & $0.0 \pm 0.0$ & $100.0 \pm 0.0$ & $43.3 \pm 2.7^{n}$ \\
\hline & medulla & $1.4 \pm 2.2$ & $48.9 \pm 3.3$ & $15.4 \pm 1.2$ \\
\hline \multirow{4}{*}{$\begin{array}{l}\text { PCV2 }(+) \text { and moderate } \\
\text { changes of follicle } \\
\text { visualization in lymph node }\end{array}$} & cortex & $7.4 \pm 15.2$ & $31.0 \pm 15.7^{\mathrm{e}}$ & $52.3 \pm 4.2$ \\
\hline & paracortex near follicule & $5.5 \pm 5.3$ & $62.7 \pm 19.1^{\mathrm{f}}$ & $42.4 \pm 2.9^{1}$ \\
\hline & paracortex near sinus & $10.1 \pm 5.3$ & $55.3 \pm 22.2^{\mathrm{g}}$ & $40.6 \pm 0.7^{n}$ \\
\hline & medulla & $5.4 \pm 1.8$ & $29.3 \pm 5.0^{\mathrm{h}}$ & $26.3 \pm 6.3$ \\
\hline \multirow{4}{*}{$\begin{array}{l}\text { PCV2 }(+) \text { and follicles were } \\
\text { not visible in lymph node }\end{array}$} & cortex & $0.0 \pm 0.0$ & - & - \\
\hline & paracortex near follicule & $3.9 \pm 3.9$ & $53.3 \pm 7.5^{f}$ & $17.2 \pm 3.3$ \\
\hline & paracortex near sinus & $7.7 \pm 1.5$ & $45.6 \pm 5.8^{\mathrm{g}}$ & $33.7 \pm 5.4^{\mathrm{n}}$ \\
\hline & medulla & $1.5 \pm 1.8$ & $22.0 \pm 11.7^{\mathrm{h}}$ & $17.3 \pm 5.8$ \\
\hline \multirow[t]{4}{*}{ PCV2 (++) } & cortex & $3.4 \pm 9.1$ & $39.8 \pm 17.0^{\mathrm{e}}$ & $51.2 \pm 7.1^{\mathrm{k}}$ \\
\hline & paracortex near follicule & $4.3 \pm 4.8$ & $58.3 \pm 16.5^{\mathrm{f}}$ & $25.9 \pm 5.7^{1}$ \\
\hline & paracortex near sinus & $7.9 \pm 4.8$ & $39.3 \pm 19.5^{\mathrm{g}}$ & $45.3 \pm 12.3^{\mathrm{n}}$ \\
\hline & medulla & $0.9 \pm 1.6$ & $23.1 \pm 9.3^{\mathrm{h}}$ & $21.4 \pm 3.5$ \\
\hline \multirow[t]{4}{*}{ PCV2 $(+++)$} & cortex & $0.0 \pm 0.0$ & $48.9 \pm 9.1^{\mathrm{e}}$ & $68.2 \pm 7.0^{\mathrm{k}}$ \\
\hline & paracortex near follicule & $2.3 \pm 4.4$ & $45.9 \pm 10.9^{f}$ & $58.1 \pm 16.6^{1}$ \\
\hline & paracortex near sinus & $4.0 \pm 4.4$ & $32.7 \pm 8.7^{\mathrm{g}}$ & $71.5 \pm 9.0^{\mathrm{n}}$ \\
\hline & medulla & $1.7 \pm 2.9$ & $17.2 \pm 5.1^{\mathrm{h}}$ & $32.8 \pm 12.6^{\mathrm{m}}$ \\
\hline
\end{tabular}

${ }^{a}$ significant difference between quantity of CD79 $\alpha$ positive cells in cortex with and without PCV2 $(\mathrm{p}<0.05)$

${ }^{b}$ significant difference between quantity of CD79 $\alpha$ positive cells in paracortex near follicle with and without PCV2 $(\mathrm{p}<0.05)$

${ }^{\mathrm{c}}$ significant difference between quantity of CD79 $\alpha$ positive cells in paracortex near sinus with and without PCV2 $(\mathrm{p}<0.05)$

${ }^{\mathrm{d}}$ significant difference between quantity of CD79 $\alpha$ positive cells in medulla with and without PCV2 $(\mathrm{p}<0.05)$

${ }^{\mathrm{e}}$ significant difference between quantity of CD3 positive cells in cortex with and without PCV2 $(\mathrm{p}<0.05)$

${ }^{\mathrm{f}}$ significant difference between quantity of CD3 positive cells in paracortex near follicle with and without PCV2 $(\mathrm{p}<0.05)$

${ }^{g}$ significant difference between quantity of CD3 positive cells in paracortex near sinus with and without PCV2 $(\mathrm{p}<0.05)$

${ }^{\mathrm{h}}$ significant difference between quantity of CD3 positive cells in medulla with and without PCV2 $(\mathrm{p}<0.05)$

${ }^{\mathrm{k}}$ significant difference between quantity of Ki67 positive cells in cortex with and without PCV2 $(\mathrm{p}<0.05)$

${ }^{1}$ significant difference between quantity of Ki67 positive cells in paracortex near follicle with and without PCV2 $(p<0.05)$

${ }^{\mathrm{n}}$ significant difference between quantity of Ki67 positive cells in paracortex near sinus with and without PCV2 $(\mathrm{p}<0.05)$

${ }^{\mathrm{m}}$ significant difference between quantity of Ki67 positive cells in medulla with and without PCV2 $(\mathrm{p}<0.05)$

follicle visualization, was observed similar quantity of CD3 positive cells and significantly differenet quantity of CD79 $\alpha$ positive cells (Table 1). These results show that B lymphocyte population was reduced at first in the lymph node with PCV2, but the number of T lymphocytes decreased later. B lymphocyte provides a humoral immunity, but $\mathrm{T}$ lymphocyte - cellular immunity (Zachary \& McGavin, 2012). These results reveal that PCV2 impact on the cellular immunity at first and after that causes changes in humoral immunity.

A significant correlation (Table 2) between the increasing number of PCV2 and number of $\mathrm{CD} 3$ positive cells in lymph node was detected (in cortex $r_{s}=0.737$, in paracortex near follicle $r_{s}=-0.633$, in paracortex near sinus $r_{s}=-0.685$, in medulla $\left.r_{s}=-0.617\right)$. The decrease of CD3 positive cells in paracortex and medulla was caused by the increasing 
Table 2

Correlation between the quantity of CD3, CD79 $\alpha$ and Ki67 positive cells in different layers of the lymph node and the quantity of PCV2 antigen

\begin{tabular}{|c|c|c|c|c|c|}
\hline $\begin{array}{l}\text { Specific cell } \\
\text { protein }\end{array}$ & $\begin{array}{l}\text { Correlation } \\
\text { parameters }\end{array}$ & Cortex & $\begin{array}{l}\text { Paracortex near } \\
\text { follicle }\end{array}$ & $\begin{array}{l}\text { Paracortex near } \\
\text { sinus }\end{array}$ & Medulla \\
\hline \multirow{3}{*}{ CD79 $\alpha$} & $r_{s}$ & $-0.587^{b}$ & $-0.339^{a}$ & -0.074 & -0.192 \\
\hline & $\mathrm{p}$ & 0.004 & 0.018 & 0.618 & 0.192 \\
\hline & $\mathrm{n}$ & 22 & 48 & 48 & 48 \\
\hline \multirow{3}{*}{ CD3 } & $r_{s}$ & $0.737^{b}$ & $-0.633^{b}$ & $-0.685^{\mathrm{b}}$ & $-0.617^{\mathrm{b}}$ \\
\hline & $\mathrm{p}$ & 0 & 0 & 0 & 0 \\
\hline & $\mathrm{n}$ & 22 & 48 & 48 & 48 \\
\hline \multirow{3}{*}{ Ki67 } & $r_{s}$ & -0.403 & $0.367^{\mathrm{a}}$ & $0.711^{\mathrm{b}}$ & $0.536^{\mathrm{b}}$ \\
\hline & $\mathrm{p}$ & 0.063 & 0.010 & 0 & 0 \\
\hline & $\mathrm{n}$ & 22 & 48 & 48 & 48 \\
\hline
\end{tabular}

a - correlation significance less than 0.05

$\mathrm{b}$ - correlation significance less than 0.01

number of PCV2. Furthermore, the increasing number of PCV2 caused the increase of CD3 positive cells in cortex (Table 2). However, the total number of CD3 positive cells was lower in lymph nodes with PCV2 than in lympn nodes without PCV2 (Table 1). T lymphocyte infiltration in cortex depends on follicle damage in cortex. Klausmann et al. (2015) study demonstrates that PCV2 strongly impacts T-cell selection processes in other lymphoid organ, - in the thymus.

Ki67 positive cells were of a very high number (92.8 cells) in cortex of lymph nodes without PCV2 (Table 1). The reason for this is a germinal centre in cortex, where cells divide all the time (Brūveris, 2015). The obtained results show that the number of $\mathrm{Ki} 67$ positive cells is significantly different in cortex of lymph nodes without PCV2 and with moderate or severe quantity of PCV2, its cells are approximately two times less in lymph nodes with PCV2 (Table 1). It is known that cortex is a $\mathrm{B}$ lymphocyte depending area (Brūveris, 2015), therefore, it can be considered that Ki67 positive cells in cortex are mainly B lymphocytes. These results revealed that PCV2 presence in the lymph node significantly decreased B lymphocytes. Other authors report a similar tendency for cell proliferation index in the lymph nodes with and without PCV2 (Lin et al., 2011). However, our results show that it does not have a significant correlation between the number of Ki67 positive cells and PCV2 quantity in lymph node (Table 2). It means that PCV2 presence in lymph node significantly decreases B lymphocyte proliferation, but B lymphocyte proliferation does not depend on PCV2 quantity in lymph nodes.

Ki67 positive cells significantly increased in paracortex and medulla depending on PCV2 increase in lymph node (Table 2). Ki67 protein contains all cells, which are active for dividing or are in the dividing process (Booth et al., 2014). It is known that paracortex is a $\mathrm{T}$ lymphocyte depending area (Brūveris, 2015). Previous study showed that PCV2 increased histiocyte number (Segales et al., 2004). Simultaneously, PCV2 decreased T lymphocytes in lymph node (Table 1, Table 2). It could be concluded that histiocytes were Ki67 positive cells in paracortex and medulla with PCV2. In another study it was found that the proliferation activity of blood monocytes and monocyte-derived macrophages (some transformation form of histiocyte) was significantly enhanced by PCV2 (Tsai et al., 2010).

$\mathrm{Ki} 67$ protein is present in all active phases of cell life cycle: interphase G1, S, G2 and mitosis. However, protein Ki67 is not observed at all in the cell's "quiet" phase G0 (Scholzen \& Gerdes, 2000). Thereby, our study showed that PCV2 did not stop B lymphocyte life cycle, but PCV2 stimulated these cells to come directly to inactive form (G0 phase). A cell in G0 phase can stay for a long time, but if it is necessary, the cell is able to return again in the active phases. However, cells in G0 phase may also become old and never renew their life cycle (Scholzen \& Gerdes, 2000). Quan et al. (2016) in vitro study shows that G0/ G1 cell cycle arrest induced by PCV2 may provide favourable conditions for viral protein expression and virus replication.

Currently, the question remains: does PCV2 delay cell cycle in G0 phase, or does PCV2 cause DNA damage, thereby, accelerating aging process of cells? Therefore, investigations in vitro by cell culture are necessary to understand PCV2 impact on the cell life cycle. It is not clear how PCV2 infection involve PCV2-mediated cell cycle arrest and contributes to virus replication. 
In vitro study shows, that PCV2 impacts the increase of cytosolic $\mathrm{Ca}^{+2}$ in cells ( $\mathrm{Gu}$ et al., 2016). This means that PCV2 possibly causes cell necrosis because of $\mathrm{Ca}^{+2}$ ion increase in the cytoplasm to activate several enzymes (endonuclease, protease, ATPase), which leads to cell death (Zachary \& McGavin, 2012). If PCV2 simultaneously impacts the ability of cell proliferation and cell necrosis, this can explain such a severe immunodeficiency and lymphopenia.

The pathogenesis of the virus still remains unresolved question. For example, why one of pigs remains healthy in the presence of PCV2 and others go on to develop clinical disease that typically results in death.

\section{Conclusion}

Morphological changes were detected in all layers of lymph nodes in pigs with PMWS. Analyzing the loss of lymphocytes in the lymph nodes in piglets with PMWS, we concluded that B lymphocyte population had been reduced at first in the lymph node with PCV2, but the number of $\mathrm{T}$ lymphocytes decreased later. PCV2 decreased B lymphocyte prolifiration activity. However, PCV2 increased cells' prolifiration activity in paracortex and medulla of lymph nodes, - it is could be associated with histiocytes infiltration in lymph nodes.

\section{References}

1. Benedict, C.A., Banks, T.A., \& Ware, C.F. (2003). Death and survival: viral regulation of TNF signaling pathways. Current Opinion in Immunology. 15, 59 - 65. DOI: 10.1016/S0952-7915(02)00018-3.

2. Booth, G.D., Takagi, M., Sanchez-Pulido, L., Petfalski, E., Vargiu, G., Samejima, K., Imamoto, N., Ponting, C.P., Tollervey, D., Cearnshaw, W., \& Vagnarelli, P. (2014). Ki-67 is a PP1-interacting protein that organises the mitotic chromosome periphery. ELife. 3. DOI: 10.7554/eLife.01641.

3. Brūveris, Z. (2015). Veterinārās histologijas pamati. (Veterinary histology basis). Rīga: SIA Medicīnas apgāds (in Latvian).

4. Darwich, L., Segales, J., \& Mateu, E. (2004). Pathogenesis of post-weaning multisystemic wasting syndrome caused by Porcine circovirus 2: an immune riddle. Archives of Virology. 149, 857 - 874. DOI: 10.1007/s00705-003-0280-9.

5. Debeer, S., Jean-Benoît, L.E., Luduec, J.B.L., Kaiserlian, D., Laurent, P., Nicolas, J.F., Dubois, B., \& Kanitakis, J. (2013). Comparative histology and immunohistochemistry of porcine versus human skin. European Journal of Dermatology. 23(4), 456 - 466. DOI: 10.1684/ejd.2013.2060.

6. Ferrari, L., Borghetti, P., De Angelis, E., \& Martelli, P. (2014). Memory T cell proliferative responses and IFN- $\gamma$ productivity sustain long-lasting efficacy of a Cap-based PCV2 vaccine upon PCV2 natural infection and associated disease. Veterinary Research. 45(44), 1 - 16. DOI: 10.1186/1297-9716-45-44.

7. García-Nicolás, O., Rosales, R.S., Pallarés, F.J., Risco, D., Quereda, J.J., Graham, S.P., Frossard, J.P., Morgan, S.B., Steinbach, F., Drew, T.W., Strickland, T.S., \& Salguero, F.J. (2015). Comparative analysis of cytokine transcript profiles within mediastinal lymph node compartments of pigs after infection with porcine reproductive and respiratory syndrome genotype 1 strains differing in pathogenicity. Veterinary Research. 46(34), 1 - 13. DOI: 10.1186/s13567-015-0161-8.

8. Gu, Y., Qi, B., Zhou, Y., Jiang, X., Zhang, X., Li, X., \& Fang, W. (2016). Porcine Circovirus Type 2 Activates CaMMK _to Initiate Autophagy in PK-15 Cells by Increasing Cytosolic Calcium. Viruses. 8(135). DOI: $10.3390 / \mathrm{v} 8050135$.

9. Hengartner, M.O. (2000). The biochemistry of apoptosis. Nature. 407, 770-776. DOI: 10.1038/35037710.

10. Irusta, P.M., Chen, Y.B., \& Hardwick, J.M. (2003). Viral modulators of cell death provide new links to old pathways. Cell Biology, 15, 700 - 705. DOI: 10.1016/j.ceb.2003.10.007.

11. Kiupel, M., Stevenson, G.W., Galbreath, E.J., North, A., HogenEsch, H., Mittal, S.K. (2005). Porcine Circovirus type 2 (PCV2) causes apoptosis in experimentally inoculated BALB/c mice. BMC Veterinary Research. 31, 7. DOI: 10.1186/1746-6148-1-7.

12. Klausmann, S., Sydler, T., Summerfield, A., Lewis, F.I., Weilenmann, R., Sidler, X., \& Brugnera, E. (2015). T-cell reprogramming through targeted CD4-coreceptor and T-cell receptor expression on maturing thymocytes by latent Circoviridae family member porcine circovirus type 2 cell infections in the thymus. Emerging Microbes \& Infections. 4(15). DOI: 10.1038/emi.2015.15.

13. Lin, C.M., Jeng, C.R., Hsiao, S.H., Liu, J.P., Chang, C.C., Chiou, M.T., Tsai, Y.C., Chia, M.Y., \& Pang, V.F. (2011). Immunopathological characterization of porcine circovirus type 2 infection-associated follicular changes in inguinal lymph nodes using high-throughput tissue microarray. Veterinary Microbiology. 149(1-2), 72 - 84. DOI: 10.1016/j.vetmic.2010.10.018. 
14. Lockshin, R.A., \& Zakeri, Z. (2004). Caspase-independent cell deaths? Oncogene. 23(16), 2766 - 2773. DOI: $10.1038 /$ sj.onc. 1207514 .

15. Opriessnig, T., Meng, X.J., \& Halbur, P.G. (2007). Porcine circovirus type 2-associated disease: Update on current terminology, clinical manifestations, pathogenesis, diagnosis, and intervention strategies. Journal of Veterinary Diagnostic Investigation. 19, 591 - 615. DOI: 10.1177/104063870701900601.

16. Polaček, V., Prodanov, J., Lazić, S., Petrović, T., Rašić, Z., \& Aleksić-Kovačević, S. (2007). Immunohistochemical detection of B and $\mathrm{T}$ lymphocytes in mandibular lymph nodes of experimentally infected piglets with classical swine fever virus. Acta veterinaria. 57(2-3), 199 - 208. DOI: 10.2478/acve2014-0020.

17. Quan, R., Wei, L., Zhu, S., Wang, J., Cao, Y., Xue, C., Yan, X., \& Liu, J. (2016). Involvement of miR-15a in G0/G1 Phase Cell Cycle Arrest Induced by Porcine Circovirus Type 2 Replication. Scientific Reports. (6). DOI: $10.1038 /$ srep27917.

18. Resendes, A.R., Majó, N., van den Ingh, T.S., Mateu, E., Domingo, M., Calsamiglia, M., \& Segalés, J. (2011). Apoptosis in postweaning multisystemic wasting syndrome (PMWS) hepatitis in pigs naturally infected with porcine circovirus type 2 (PCV2). Veterinary journal. 189(1), 72 - 76. DOI: 10.1016/j. tvj1.2010.06.018.

19. Resendes, A.R., Majo, N., Segales, J., Mateu, E., Calsamiglia, M., \& Domingo, M. (2004). Apoptosis in lymphoid organs of pigs naturally infected by porcine circovirus type 2. Journal of General Virology. 85, 2837 - 2844. DOI: 10.1099/vir.0.80221-0.

20. Rosell, C., Segalés, J., Plana-Durán, J., Balasch, M., Rodr'1guez-Arrioja, G.M., Kennedy, S., Allan, G.M., McNeilly, F., Latimer, K.S., \& Domingo, M. (1999). Pathological, immunohistochemical, and in situ hybridization studies of natural cases of postweaning multisystemic wasting syndrome (PMWS) in pigs. Journal of Comparative Pathology. 120, 59 - 78. DOI: 10.1053/jcpa.1998.0258.

21. Sanchez, R.E., Meerts, P., Nauwynck, H.J., \& Pensaert, M.B. (2003). Change of porcine circovirus 2 target cells in pigs during development from fetal to early postnatal life. Veterinary Microbiology. 95, 15 - 25. DOI: $10.1016 / \mathrm{S} 0378-1135(03) 00120-2$.

22. Scholzen, T., \& Gerdes, J. (2000). The Ki-67 protein: from the known and the unknown. Journal of Cellular Physiology. 182(3), 311 - 322. DOI: 10.1002/(SICI)1097-4652(200003)182:3<311::AID-JCP1>3.0.CO ;2-9.

23. Segalés, J., \& Domingo, M. (2002). Postweaning multisystemic wasting syndrome (PMWS) in pigs. A review. Veterinary Quarterly. 24, 109 - 124. DOI: 10.1080/01652176.2002.9695132.

24. Segales, J., Domingo, M., Chianini, F., Majo, N., Dominguez, J., Darwich, L., \& Mateu, E. (2004). Immunosuppression in post-weaning multisystemic wasting syndrome affected pigs. Journal of Veterinary microbiology. 98, 151 - 158. DOI: 10.1016/j.vetmic.2003.10.007.

25. Stankevicius, A., Sibila, M., Čepulis, R., \& Segales, J. (2007). First description of porcine circovirus type 2 associated diseases in Lithuania and Latvia. In Proceedings of 5th international symposium on emerging and re-emerging pig disease: PMWS, PRRS, Swine influenza and associated diseases. 24 - 27 June 2007 (pp. 82). Kraków, Poland: PHU Kopiorama.

26. Tsai, Y.C., Jeng, C.R., Hsiao, S.H., Chang, H.W., Liu, J.J., Chang, C.C., Lin, C.M., Chia, M.T., \& Pang, V.F. (2010). Porcine circovirus type 2 (PCV2) induces cell proliferation, fusion, and chemokine expression in swine monocytic cells in vitro. Veterinary Research. 41(5), 60. DOI: 10.1051/vetres/2010032.

27. Zachary, J.F., \& McGavin, M.D. (2012). Pathological basis of veterinary disease (5th ed.). USA: Elsevier. 